\title{
Antibodies to Mycobacterium paratuberculosis and nine species of environmental mycobacteria in Crohn's disease and control subjects
}

\author{
K J Stainsby, J R Lowes, R N Allan, J P Ibbotson
}

\begin{abstract}
Cultural and serological studies have provided limited, often conflicting, evidence of a role for mycobacteria in the pathogenesis of Crohn's disease. Interest has focussed on Mycobacterium paratuberculosis, previously considered to be common in the environment with no major role as a human pathogen. Whether a specific serum antibody response to mycobacteria occurs in Crohn's disease or ulcerative colitis was investigated. Sera from patients with Crohn's disease $(n=38)$, ulcerative colitis $(n=15)$, and a healthy control population $(n=30)$ were assayed in an enzyme linked immunosorbent assay (ELISA) using eight filtered sonicate mycobacterial preparations and a purified protein derivative made from the bovine tubercle bacillus. In addition, IgG, IgM, and IgA levels to $M$ paratuberculosis were determined in sera from patients with active $(n=24)$ or inactive $(n=29)$ Crohn's disease and the control populations. There was strong evidence of contact with environmental mycobacteria in all patients and control populations, with the greatest responses to preparations of $M$ avium, $M$ tuberculosis, and $M$ kansasii. A large proportion of patients with Crohn's disease had antibodies that bound most antigens tested but there were no statistical differences between these values and those of the control population. Similarly, there were no differences in antibody levels to $M$ paratuberculosis in patient and control groups. Although a subset of patients with active Crohn's disease (25\%) had IgG concentrations that exceeded the control mean by more than $2 \mathrm{SD}$, this phenomenon may not be specific to Crohn's disease: $20 \%$ of a small group of patients with coeliac disease had similarly raised IgG levels to $M$ paratuberculosis. These findings do not provide serological evidence of a role for this organism in the pathogenesis of Crohn's disease. (Gut 1993; 34: 371-374)
\end{abstract}

Early descriptions of Crohn's disease noted the similarity between this disorder and intestinal tuberculosis, prompting several unsuccessful searches for a causal linked with mycobacteria..$^{12}$ Interest in mycobacteria was renewed by the isolation of Mycobacterium kansasii from a lymph node of a patient with Crohn's disease. ${ }^{3}$ The same group isolated cell wall-deficient forms from the lymph nodes of 42 of 76 patients with Crohn's disease, 14 of 27 patients with ulcerative colitis, and three of 41 controls. ${ }^{+}$These resembled chemically induced cell wall-deficient forms of
$M$ kansasii and corynebacteria, and contained mycolic acids. $M$ paratuberculosis and spheroplast forms have been isolated from patients with Crohn's disease but not from patients with ulcerative colitis or controls. ${ }^{56}$ These isolates have been identified by both restriction polymorphism of the ribosomal $5 \mathrm{~S}$ genes ${ }^{7}$ and studies of random gene sequences being identical to the wild-type organism. ${ }^{8}$ Other species of mycobacteria isolated from tissues of patients with inflammatory bowel disease include those from the MAI complex, $M$ fortuitum, and $M$ kansasii. ${ }^{9}$ These species have also been isolated in control tissues, highlighting the ubiquitous nature of mycobacteria and throwing doubt on the relevance of the association between mycobacteria and inflammatory bowel disease.

There has not yet been any consistent or convincing serological evidence of a causal role for mycobacteria in Crohn's disease. Indirect fluorescent antibody asays to $M$ kansasii antigens yielded positive results in nine of 11 patients with Crohn's disease but not in 33 controls. ${ }^{10}$ These results, however, could not be reproduced by the same workers" ${ }^{11}$ and the organism was undetectable in Crohn's disease tissues by immunofluorescence. ${ }^{12}$ Patients and controls respond equally to $M$ kansasii skin test reagents and a similar lack of specificity has been observed with serum agglutination of $M$ paratuberculosis and $M$ avium. ${ }^{13}$ Despite reports of enzyme linked immunosorbent assays (ELISA) showing raised antibody titres to $M$ tuberculosis ${ }^{14}$ and $M$ paratuberculosis in Crohn's disease, ${ }^{15}$ other studies have failed to confirm these findings. ${ }^{16}{ }^{17}$ In view of this, and the possibility that the isolates of $M$ paratuberculosis are simply environmental strains 'passing through' the gut, ${ }^{17}$ we have investigated the association between Crohn's disease and a range of mycobacterial species by examining immunoglobulin concentrations in sera from patients and controls in response to $M$ paratuberculosis and nine antigen preparations of predominantly environmental strains of mycobacteria.

\section{Patients and methods}

\section{SERUM SAMPLES}

Sera from 38 patients with Crohn's disease, 15 patients with ulcerative colitis, and 30 blood transfusion volunteers were used in the study of immunoglobulin levels to the nine species of mycobacteria. Fifty three additional samples (24 active and 29 inactive) from patients with Crohn's disease were included in the study of $\operatorname{IgG}, \operatorname{IgM}$, and IgA levels to $M$ paratuberculosis as were 10 
samples from patients with coeliac disease. Inflammatory bowel disease was considered active if there was evidence of a raised platelet count, $\mathrm{C}$ reactive protein, or $\alpha 1$ acid glycoprotein. All serum samples were coded and tested blind.

\section{ANTIGENS}

The antigens used in this study were filtered sonicate preparations of the eight mycobacterial species listed in Table I (Donated by Dr J L Stanford, University College and Middlesex Hospital Medical School, London). The method of preparation is described in detail elsewhere. ${ }^{18}$ Briefly, organisms grown on Sauton's medium solidified with $1.5 \%$ agar were harvested, suspended in $\mathrm{M} / 15$ borate buffered saline ( $\mathrm{pH}$ $8 \cdot 0)$, and ultrasonicated. Preparations were then filtered $(0.2 \mu \mathrm{m}$ pore size $)$ and protein concentrations were determined spectrophotometrically. Dilutions of $10 \mu \mathrm{g} / \mathrm{ml}$ in $M / 20$ sodium carbonate coating buffer ( $\mathrm{pH} 9 \cdot 6$ ) were used to coat microtitre plates. Purified protein derivatives prepared from the bovine tubercle bacillus and $M$ paratuberculosis (a gift from Val Barnard, MAFF, Central Veterinary Laboratory, Weybridge) were also used at a concentration of $10 \mu \mathrm{g} / \mathrm{ml}$.

\section{ELISA}

The method used to determine total immunoglobulin values was similar to that described elsewhere, ${ }^{190}$ except the serum samples and peroxidase conjugated rabbit anti-human immunoglobulins (Dakopatts, UK) were diluted 1:1000. To avoid cross reactivity, rabbit antihuman immunoglobulins, which had been produced without the use of Freund's complete adjuvant, were used. Each serum sample was tested in duplicate against each antigenic reagent and the results taken as the mean absorbance

TABLE I Effect of disease activity on antibody levels to nine mycobacterial species

\begin{tabular}{|c|c|c|c|c|c|}
\hline & \multicolumn{2}{|l|}{ Crohn's disease } & \multicolumn{2}{|l|}{ Ulcerative colitis } & \multirow[b]{2}{*}{$\begin{array}{l}\text { Controls } \\
(n=30)\end{array}$} \\
\hline & $\begin{array}{l}\text { Active } \\
(n=16)\end{array}$ & ${ }_{(n=22)}^{\text {Inactive }}$ & $\begin{array}{l}\text { Active } \\
(n=8)\end{array}$ & $\begin{array}{l}\text { Inactive } \\
(n=7)\end{array}$ & \\
\hline $\begin{array}{l}M \text { intracellulare } \\
M \text { avium } \\
M \text { kansasii } \\
M \text { tuberculosis } \\
M \text { vaccae } \\
M \text { neoaurum } \\
M \text { xenopi } \\
\text { PPD B } \\
M \text { rhodesiae }\end{array}$ & $\begin{array}{c}64 \cdot 5(18 \cdot 5 ; 2) \\
54 \cdot 2(18 \cdot 2 ; 1) \\
51 \cdot 2(19 \cdot 2 ; 2) \\
52 \cdot 6(23 \cdot 1 ; 2) \\
36 \cdot 9(22 \cdot 7 ; 2) \\
15 \cdot 5(6 \cdot 9 ; 1) \\
7 \cdot 9(2 \cdot 4 ; 0) \\
8 \cdot 1(4 \cdot 4 ; 4) \\
5 \cdot 8(2 \cdot 3 ; 4)\end{array}$ & $\begin{array}{c}58 \cdot 5(19 \cdot 6 ; 0) \\
48 \cdot 6(16 \cdot 1 ; 0) \\
46 \cdot 0(14 \cdot 7 ; 0) \\
47 \cdot 1(14 \cdot 8 ; 0) \\
31 \cdot 5(17 \cdot 9 ; 1) \\
14 \cdot 1(4 \cdot 3 ; 0) \\
8 \cdot 2(3 \cdot 0 ; 0) \\
7 \cdot 1(2 \cdot 6 ; 0) \\
5 \cdot 4(1 \cdot 5 ; 1)\end{array}$ & $\begin{array}{c}46 \cdot 0(20 \cdot 0 ; 0) \\
37 \cdot 1(13 \cdot 1 ; 0) \\
35 \cdot 5(15 \cdot 3 ; 0) \\
37 \cdot 4(16 \cdot 0 ; 0) \\
23 \cdot 5(9 \cdot 7 ; 0) \\
15 \cdot 6(8 \cdot 1 ; 1) \\
8 \cdot 6(4 \cdot 9 ; 0) \\
9 \cdot 3(4 \cdot 4 ; 1) \\
5 \cdot 9(3 \cdot 7 ; 2)\end{array}$ & $\begin{array}{c}55 \cdot 3(23 \cdot 3 ; 1) \\
46 \cdot 0(17 \cdot 1 ; 0) \\
42 \cdot 3(14 \cdot 7 ; 0) \\
46 \cdot 7(17 \cdot 6 ; 0) \\
38 \cdot 9(17 \cdot 9 ; 0) \\
17 \cdot 1(7 \cdot 9 ; 1) \\
8 \cdot 4(2 \cdot 2 ; 0) \\
8 \cdot 6(4 \cdot 2 ; 1) \\
6 \cdot 3(2 \cdot 9 ; 1)\end{array}$ & $\begin{array}{c}53 \cdot 1(22 \cdot 0 ; 2) \\
46 \cdot 6(20 \cdot 6 ; I) \\
43 \cdot 9(19 \cdot 5 ; I) \\
49 \cdot 6(23 \cdot 0 ; I) \\
34 \cdot 1(21 \cdot 5 ; I) \\
13 \cdot 0(6 \cdot 4 ; 2) \\
8 \cdot 4(10 \cdot 1 ; I) \\
7 \cdot 4(3 \cdot 6 ; I) \\
3 \cdot 6(1 \cdot 9 ; 2)\end{array}$ \\
\hline
\end{tabular}

Figures shown are mean values $(\times 100)$ and $S D$ and number of position samples are in parenthesis (Antibody levels exceeding the mean of the control population by $2 \mathrm{SD}$ are given in italics.

TABLE II Immunoglobulin levels to Mycobacterium paratuberculosis in patients with inflammatory bowel disease and controls

\begin{tabular}{llll}
\hline & IgG & IgM & IgA \\
\hline Active Crohn's $(n=24)$ & $23 \cdot 0(18 \cdot 8 ; 6)$ & $18 \cdot 3(10 \cdot 2 ; 0)$ & $20 \cdot 0(14 \cdot 4 ; 0)$ \\
Inactive Crohn's $(n=29)$ & $17 \cdot 9(13 \cdot 0 ; 2)$ & $13 \cdot 6(7 \cdot 3 ; 0)$ & $14 \cdot 4(10 \cdot 9 ; 0)$ \\
Ulcerative Colitis $(n=10)$ & $15 \cdot 8(6 \cdot 5 ; 0)$ & $\mathrm{N} / \mathrm{T}$ & $\mathrm{N} / \mathrm{T}$ \\
Coeliac Disease $(n=11)$ & $17 \cdot 8(13 \cdot 2 ; 2)$ & $\mathrm{N} / \mathrm{T}$ & $\mathrm{N} / \mathrm{T}$ \\
Healthy Control $(n=23)$ & $20 \cdot 0(6 \cdot 5 ; 0)$ & $25 \cdot 8(16 \cdot 2 ; 0)$ & $14 \cdot 6(12 \cdot 3 ; 0)$
\end{tabular}

Figures shown are mean readings $(\times 100)$ and standard deviations. The italic figures are the number of samples in which antibody levels exceeded the mean of the healthy control population by more than two SD. value minus the absorbance of wells incubated with the antigen alone. Results are shown as whole numbers - that is, mean absorbance values to two decimal places multiplied by 100 .

IgG, IgM, and IgA levels to $M$ paratuberculosis were also determined in an indirect ELISA, but employing alkaline phosphatase anti-human IgG, IgM, or IgA conjugates (Sigma) and serum samples diluted 1:100.

STATISTICAL METHODS

Statistical analysis was by Students $t$ test.

\section{Results}

\section{IMMUNOGLOBULIN LEVELS TO $M$}

\section{PARATUBERCULOSIS}

Table II shows the ELISA results comparing IgG, IgM, and IgA levels to $M$ paratuberculosis in Crohn's disease patients with those in patients with ulcerative colitis and healthy controls. There were no significant differences in levels of IgG, IgM, or IgA between the patient and control populations, although there was a distinct subset of patients with active Crohn's disease (25\% compared with $7 \%$ of those with inactive disease and no controls) who had high IgG levels (>mean of the control population $+2 \mathrm{SD}$ ). However, $20 \%$ of the small number of samples studied from patients with coeliac disease also had high levels of IgG.

\section{IMMUNOGLOBULIN LEVELS TO PREDOMINANTLY} ENVIRONMENTAL SPECIES OF MYCOBACTERIA

Similar results were obtained when total immunoglobulin levels to the nine other mycobacterial species were examined (Figure): There were no significant differences between the various patients populations in terms of antibody levels to any of the species studied. In patients with Crohn's disease, however, there was a trend towards increased antibody levels to $M$ avium and $M$ intracellulare. Patients with active Crohn's disease were again more likely to possess high antibody levels than were patients with ulcerative colitis and controls (Table I): $25 \%$ of patients with active Crohn's disease had antibody titres, to one or more of the mycobacterial species tested, which exceeded the mean plus $2 \mathrm{SD}$ of the control population. This occurred in only $9 \%$ of patients with inactive crohn's disease and $7 \%$ of the healthy control population. In the small number of patients with disease restricted to the small or large bowel, there was no difference in observed antibody levels (data not shown).

\section{Discussion}

Several mycobacterial species, especially $M$ paratuberculosis and $M$ kansasii, have been implicated in the aetiology of Crohn's disease. As most chronic infections, including mycobacterial diseases of man and animals, have an associated serological response, our studies do not provide strong evidence to support the proposed role of mycobacteria in the pathogenesis of inflammatory bowel disease. Overall, serological 


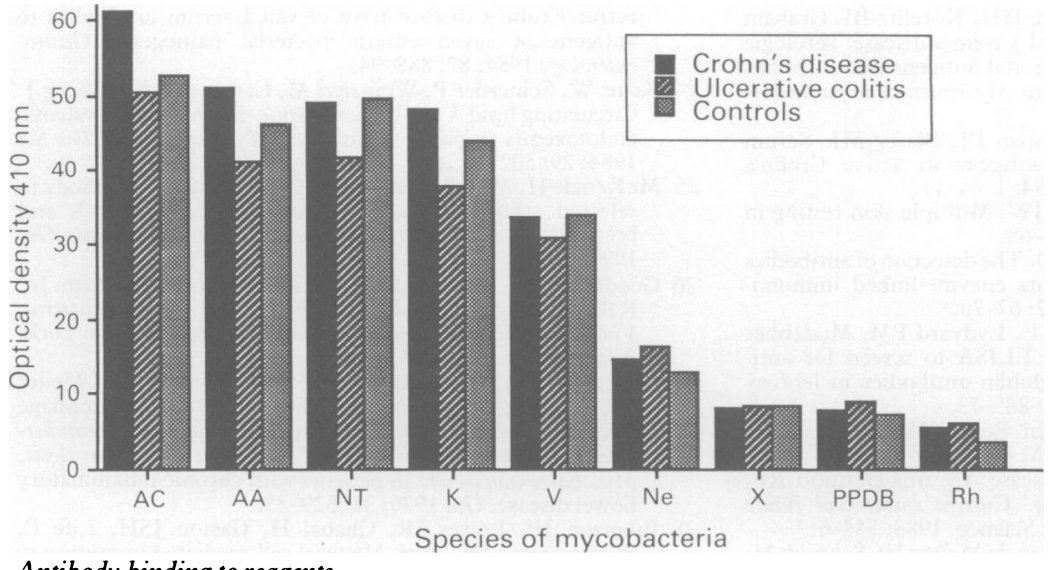

Antibody binding to reagents prepared from nine species of mycobacteria in populations of patients with Crohn's disease, ulcerative colitis and controls $(A C=M$ intracellulare, $A A=M$ avium, $N T=M$ tuberculosis, $K=M$ kansasii, $V=M$ vaccae, $\mathrm{Ne}=M$ neoaurum, $X=M$ xenopi, $P P D B=$ bovine tubercle bacillus purified protein derivative, $R h=M$ rhodesiae. antibody levels of patient and control populations. In addition, it has been suggested that the lack of a distinct immune response to certain mycobacterial antigens may be the result of a lack of these antigens in the cell wall deficient forms thought to cause Crohn's disease. ${ }^{17}$ Our results further emphasise the need for $M$ paratuberculosis specific antigen preparations to be employed in such studies of humoral immunity.

The histology of Crohn's disease, however, suggests that the host response is primarily cell mediated, and so studies of cell mediated immunity to mycobacterial antigens may be more relevant. However, studies using peripheral blood lymphocytes ${ }^{27}$ and mesenteric lymph node lymphocytes ${ }^{28}$ have also failed to provide evidence of mycobacterial involvement in Crohn's disease.

The data presented here and previously by others suggest that the presence of mycobacteria in the tissues of patients with Crohn's disease may simply be the result of secondary invasion of a previously damaged mucosa and that the slightly raised antibody levels are also a secondary phenomenon, without relevance to the primary pathogenesis of Crohn's disease.

This work was presented at the Spring meeting of the British Society of Gastroenterology, Sheffield, March 1992 and published as an abstract. The authors are grateful to Dr J Stanford for the as an abstract. The authors are grateful to Dr J Stanford for the provision of mycobacterial sonicates and would like to acknowledge funding from the National Association for Colitis and
Crohn's Disease and a British Digestive Foundation/Lilly Crohn's Disease and
Industries Fellowship. control as well as patient populations. This was in addition to a baseline response to mycobacterial group $i$ common antigen, reflecting the ubiquitous nature of mycobacteria in the environment. Antibodies were mainly directed at the sonicates of the MAI complex, $M$ tuberculosis, and $M$ kansasii and may indicate recognition of the group ii antigens of these organisms.

It is tempting to correlate the finding in a subset of patients with positive antibody levels to $M$ paratuberculosis ( $25 \%$ of those with active Crohn's disease) with the isolation of $M$ paratuberculosis from tissues of patients with Crohn's disease. However, the differences in responses between the various populations was minimal, with only a modest trend towards increased antibody levels to mycobacteria in patients with Crohn's disease. It is well documented that patients with Crohn's disease often have an increased antibody response to a range of other micro-organisms, including enterobacterial species $^{22-24}$ and Saccharomyces cerevisiae. ${ }^{25}$ As much contact with these species and environmental mycobacteria is via the oral route, presumably through a defective barrier function of the gut mucosa, it has been proposed that the organisms may be just 'passing through'. ${ }^{1623}$ Indeed, several species of environmental mycobacteria have been isolated from both inflammatory bowel disease and histologically normal tissues. ${ }^{9}$

Given the taxonomic similarities between mycobacterial species, ${ }^{26}$ it is not surprising that there is extensive cross reactivity between $M$ paratuberculosis and both $M$ kansasii $(52.5 \%)$ and $M$ tuberculosis (39\%). ${ }^{15}$ Cho et al ${ }^{16}$ stressed the cross reactive nature of mycobacterial antigens, the effect of environmental priming, and how this might prevent differentiation between the
1 Dalziel TK. Chronic intestinal enteritis. BMF 1913 ii: 106870.

2 Crohn BB, Ginzburg L, Oppenheimer GD. Regional ileitis: a pathologic and clinical entity. $\mathcal{F} A M A$ 1932; 99: 1323-9.

3 Burnham WR, Lennard-Jones JE. Mycobacteria as a possible cause of inflammatory bowel disease. Lancet 1978; ii: 693-6.

4 Stanford JL, Dourmashkin R, McIntyre G, Visuvanathan S. part might they play in the aetiology of Crohn's disease. In: MacDermott RP, ed. Inflammatory bowel disease. Current status and future approach. Amersterdam: Elsevier Science,

5 Chiodini RJ, Kruiningen HJ, Thayer WR, Merkal RS, Coutu $\mathrm{JA}$. Possible role of mycobacteria in inflammatory bowel disease. 1: An unclassified Mycobacterium species isolated from patients with Crohn's disease. Dig Dis Sci 1984; 29: 1073-9.

6 Chiodini RJ, Van Kruiningen HJ, Thayer WR, Merkal RS, Coutu JA. The sheroplastic phase of mycobacteria isolated from patients with Crohn's disease. $\mathcal{F}$ Clin Microbiol 1986; 24: 357-63.

7 Chiodini RJ. Identification of mycobacteria from Crohn's disease by restriction polymorphism of the $5 \mathrm{~s}$ ribosomal DNA genes. In; MacDermott RP, ed. Inflammatory bowel disease. Current status and future approach. Amsterdam; disease. Current status and future

8 McFadden JJ, Butcher PD, Chiodini RJ, Hermon-Taylor J. Crohn's disease isolated mycobacteria are identical to $M y c o-$ bacterium paratuberculosis, as determined by DNA probes that distinguish between mycobacterial species. $f$ Clin Microbiol 1987; 25: 796-801.

9 Graham DY, Markesich DC, Estes MK, Yoshimura HH Mycobacteria and inflammatory bowel disease: culture and DNA hybridization. Gastroenterology 1985; 90: 1436.

10 White S, Nassau E, Burnham W, Stanford JL, Lennard-Jones JE. Further evidence for a mycobacterial aetiology of JE. Further evidence for a mycobac
Crohn's disease. Gut 1978; 19: 443-4.

11 Elliot P, Lennard-Jones JE, Burnham W, White S, Stanford JL. Further data on skin testing with mycobacterial antigens JL. Further data on skin testing with myco

12 Whorwell PJ, Davidsin IW, Beeken WL, Wright R. Search by immunofluroescence for antigens of rotavirus, Pseudomona maltophilia and Mycobacterium kansasii in Crohn's disease.

13 Matthews N, Mayberry JF, Rhodes J, Neale L, Munro J, Wensinck F, et al. Agglutinins to bacteria in Crohn's disease. Gut 1980; 21 : 376-80.

14 Grange JM, Gibson J, Nassau E. Emzyme-linked immunosorbent assay (ELISA). A study of antibodies to Mycobacterium tuberculosis in the IgG, IgA and IgM classes in tuberculosis, sarcoidosis and Crohn's disease. Tubercle 1980 61: 145-52.

15 Thayer WR, Coutu JA, Chiodini RJ, Van Kruiningen HJ Merkal RS. The possible role of mycobacteria in inflammatory bowel disease. II. Mycobacterial antibodies in Crohn's disease. Dig Dis Sci 1984; 29: 1080-5.
Do mycobacteria exist in alternative physical forms and what 1988; 503-8. Lancet 1979; ii: 697-8. 
16 Cho SN, Brennan PJ, Yoshimura HH, Korelitz BI, Graham DY. Mycobacterial aetiology of Crohn's disease: serologic study using common mycobacterial antigens and a species specific glycolipid antigen from Mycobacterium paratuberculosis. Gut 1986; 27: 1353-6.

17 Kobayashi K, Brown WR, Brennan PJ, Blaser MJ. Serum antibodies to mycobacterial antigens in active Crohn's disease. Gastroenterology 1988; 94: 1404-11.

18 Paul RC, Stanford JL, Carswell JW. Multiple skin testing in leprosy. F Hygiene 1975; 75: 57-68.

19 Nassau E, Parsons R, Johnson GD. The detection of antibodies to $M$. tuberculosis by microplate enzyme-linked immunosorbent assay. Tubercle 1976; 57: 67-70.

20 Bahr GM, Rook GAW, Moreno E, Lydyard PM, Modabber PZ, Stanford JL. Use of the ELISA to screen for antithymocyte and anti- 32 -microgloblin antibodies in leprosy and SLE. Immunology 1980; 41: 865-73.

21 Jiwa NM, Mulder CJJ, van den Berg FM, Tytgat GNJ Haagsma J, Walboomers JMM. Elevated IgG to mycobacterial species in Crohn's disease. In: MacDermott RP bacterial species in Crohn's disease. In: MacDermott RP, ed. Inflammatory bowel disease. Current status and

22 Auer IO, Roder F, Wensinck F, van de Merwe JP, Schmidt H Selected bacterial antibodies in Crohn's disease and ulcerative colitis. Gastroenterology 1983; 18: 217-23.

23 Blaser MJ, Miller RA, Lacher J, Singleton JW. Patients with active Crohn's disease have elevated serum antibodies to antigens of seven enteric bacterial pathogens. Gastroenterology 1984; 87: 888-94.

24 Kruis W, Schussler P, Weinzierl M, Caranos C, Eisenburg J. Circulating lipid $\mathrm{A}$ antibodies despite the absence of systemic endotoxemia in patients with Crohn's disease. Dig Dis Sci 1984; 29: 502-7.

25 McKenzie H, Main J, Pennington CR, Parratt D. Antibody to selected strains of Saccharomyces cerevisiae (baker's and brewer's yeast) and Candida albicans in Crohn's disease. Gut 1990; 31: 536-8.

26 Goodfellow M, Wayne LG. Taxonomy and nomenclature. In: Ratledge C, Stanford J, eds. The biolology of mycobacteria. Vol l. Physiology, identification and classification. New York: Academic Press, 471-521.

27 Seldenriik CA, Drexhage HA, Meuwissen SGM, Meijer CJLM. T-cellular immune reactions (in macrophage inhibition factor assays) against Mycobacterium paratuberculosis, Mycobacterium kansasii, Mycobacterium tuberculosis, Mycobacterium avium in patients with chronic inflammatory Mycobacternum avium in patients with
bowel disease. Gut 1990; 31: 529-35.

28 Ibbotson JP, Lowes JR, Chahal H, Gaston JSH, Life P, Kumararatne DS, et al. Mucosal cell-mediated immunity to mycobacterial, enterobacterial and other microbial antigens in inflammatory bowel disease. Clin Exp Immunol 1992; 87: 224-30. 